\title{
WORKSHOP PEMBUATAN RANGKAIAN ELEKTRONIKA SEDERHANA PADA KELOMPOK SWADAYA MASYARAKAT (KSM) NYIUR
}

\author{
Nifty Fath"), Rummi Sirait ${ }^{1}$, Eka Purwa Laksana1) \\ 1)Program Studi Teknik Elektro, Fakultas Teknik, Universitas Budi Luhur, Jakarta, Indonesia \\ Corresponding author : Nifty Fath \\ E-mail : nifty.fath@budiluhur.ac.id
}

Diterima 16 Januari 2021, Direvisi 28 Januari 2021, Disetujui 03 Maret 2021

\begin{abstract}
ABSTRAK
Kelompok Swadaya Masyarakat Nyiur merupakan pusat kreasi dan inovasi daur ulang yang berada di Kelurahan Petukangan Utara, Kecamatan Pesanggrahan, Jakarta Selatan. Beberapa program yang diadakan oleh KSM Nyiur adalah rumah belajar Nyiur, klinik daur ulang Nyiur, rumah pupuk Nyiur, dan pertanian Nyiur. Ketrampilan dalam bidang elektronika belum menjadi salah satu program dari Kelompok Swadaya Nyiur. Padahal, skill dalam pembuatan rangkaian elektronika sederhana, jika dipelajari lebih lanjut, dapat menjadi modal untuk membuka usaha dalam bidang elektronika yang bermanfaat. Oleh karena itu, perlu adanya suatu kegiatan yang dapat membangun serta mengembangkan ketrampilan ke arah peningkatan wawasan dan kreatifitas dalam bidang elektronika. Kegiatan workshop pembuatan rangkaian elektronika sederhana pada KSM Nyiur telah dilakukan dengan metode pemaparan materi dan praktek secara langsung merangkai lampu senter sederhana. Sasaran dari kegiatan ini adalah warga RT 010 / RW 02 Kelurahan Petukangan Utara, Kecamatan Pesanggrahan, Jakarta Selatan, khususnya warga usia sekolah. Berdasarkan hasil evaluasi di akhir agenda workshop, warga telah dapat memahami beberapa dasar komponen elektronika serta dapat merakit sendiri lampu senter sederhana dengan alat dan bahan yang mudah didapatkan.
\end{abstract}

Kata kunci: rangkaian elektronika sederhana; workshop; kreatifitas.

\begin{abstract}
"Kelompok Swadaya Masyarakat (KSM) Nyiur" is a recycling creation and innovation center located in Petukangan Utara Village, Pesanggrahan District, South Jakarta. Some of the programs held by the Nyiur KSM are the learning house, recycling clinic, fertilizer house, and farming. However, electronics skills have not been part of the KSM Nyiur programs. In fact, skills on making simple electronic circuits, if studied further, can be an asset to open a business in the field of electronics that is useful. Therefore, it is necessary to have an activity that can build and develop skills towards increasing insight and creativity in the field of electronics. A workshop on making simple electronic circuits at KSM Nyiur was held with the method of presenting the material and practicing directly assembling a simple flashlight. The target of this activity is school-age residents in RT 010 / RW 02. Based on the results of the evaluation at the end of the workshop agenda, residents have been able to understand some basic electronic components and can assemble a simple flashlight by themselves with easily available tools and materials.
\end{abstract}

Keywords: electronic circuit; workshop; creativity style.

\section{PENDAHULUAN}

Kelompok Swadaya Masyarakat (KSM) Nyiur merupakan pusat kreasi dan inovasi daur ulang yang berada di Jalan Haji Gaim No. 50 RT 010 / RW 02 Kelurahan Petukangan Utara, Kecamatan Pesanggrahan, Jakarta Selatan, yang terletak pada lokasi seperti yang terlihat pada Gambar 1. Visi dari KSM Nyiur adalah menjadi KSM yang mandiri dan berperan aktif secara berkelanjutan untuk menggiatkan dan memberikan proses pembelajaran masyarakat untuk lebih peduli terhadap lingkungan.
Beberapa program yang diadakan oleh KSM Nyiur adalah rumah belajar nyiur, klinik daur ulang nyiur, program jambanisasi warga, rumah pupuk nyiur, dan pertanian nyiur (Rakyat, 2015) Sebagian besar mata pencaharian warga yang tergabung dalam KSM Nyiur adalah pedagang, ojek, guru, pekerja kantoran, penjahit (konveksi), dan driver. Saat ini, kegiatan di bidang elektronika di KSM Nyiur masih sangat minim. Padahal, produk elektronika praktis sudah menjadi kebutuhan dasar dalam rumah tangga (Kebudayaan, 2015). Selain itu, produk 
elektronika sederhana dapat mengembangkan sumber daya yang ada untuk menjadikan nilai tambah pada komponen dan material apabila produk elektronika tersebut diproduksi dan dijual.

Amri dan Stephan dalam jurnal (Amri \& Stephan, 2020) melakukan pelatihan reparasi peralatan elektronik rumah tangga yakni lampu penerangan LED. Hal ini dikarenakan lampu penerangan rumah adalah peralatan elektronika yang paling sering digunakan dalam rumah tangga. Beberapa pelatihan terkait perancangan peralatan elektronik untuk usia sekolah dan usia produktif juga dilakukan oleh (Mohammad Fadly Syah Putra et al., 2017), (Risnandar et al., 2019), dan (Sekarsari \& Sunardi, 2020).

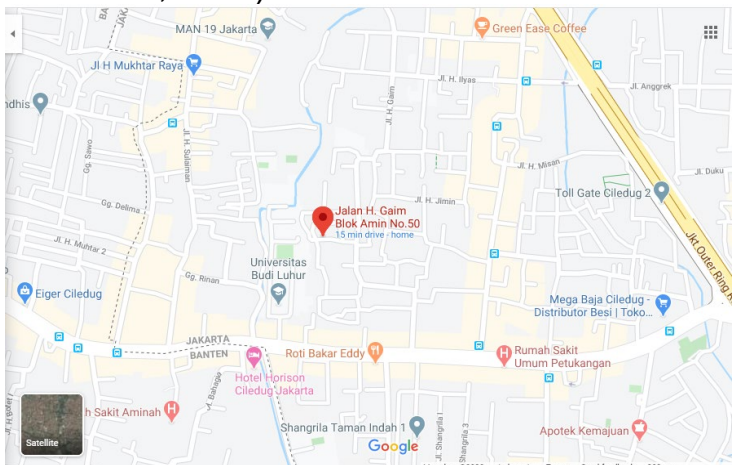

Gambar 1. Lokasi Kelompok Swadaya Nyiur

Untuk warga usia sekolah, era globalisasi juga menuntut untuk memiliki keterampilan selain yang diperoleh di bangku sekolah agar dapat diaplikasikan dalam rumah tangga maupun masyarakat luas (Atmam et al., 2018), (Atmam et al., 2017), (Waluyo, 2018).

Oleh karena itu, perlu adanya suatu kegiatan yang dapat meningkatkan wawasan dan kreatifitas serta mengembangkan ketrampilan praktikal dalam bidang elektronika yakni "Workshop Pembuatan Rangkaian Elektronika Sederhana". Rangkaian elektronika sederhana yang dipraktekkan dalam kegiatan ini adalah membuat lampu senter sederhana dan mempelajari cara merangkai dispenser hand-sanitizer otomatis.

Workshop ini diharapkan dapat membekali diri warga ke arah peningkatan skill dalam bidang elektronika untuk warga usia dewasa dan terlebih guna mempersiapkan diri untuk melanjutkan jenjang perguruan tinggi atau dunia kerja yang memerlukan keterampilan untuk menggapai masa depan yang cerah untuk warga usia sekolah. Disamping itu, tujuan utama dari kegiatan workshop ini adalah untuk menggali dan meningkatkan keterampilan warga di bidang elektronika yang dapat bermanfaat bagi kehidupan sehari-hari.

\section{METODE}

Untuk menyelaraskan program kerja KSM Nyiur sebagai rumah belajar, maka disusunlah suatu instrumen kegiatan pengabdian pada masyarakat dalam bentuk workshop pembuatan rangkaian elektronika sederhana. Lokasi kegiatan berada di rumah belajar KSM Nyiur di Jalan Haji Gaim No. 50 RT 010 / RW 02 Kelurahan Petukangan Utara, Kecamatan Pesanggrahan, Jakarta Selatan. Sasaran dari kegiatan ini adalah seluruh warga RT 010 / RW 02 Kelurahan Petukangan Utara, Kecamatan Pesanggrahan, Jakarta Selatan, khususnya warga usia sekolah.

Tahapan yang dilakukan dalam kegiatan ini diawali dengan studi lapangan di KSM Nyiur. Tim melakukan diskusi dengan ketua pengelola KSM Nyiur yakni Umi Tutik Asmawi terkait kebutuhan masyarakat akan produk elektronika sederhana. Tahap selanjutnya adalah memaparkan solusi, menetapkan rencana kegiatan, dan membuat perjanjian kerja sama.

Langkah dalam pembuatan produk elektronika sederhana yang dilakukan dalam pengabdian kepada masyarakat ini terlihat pada Gambar 2.

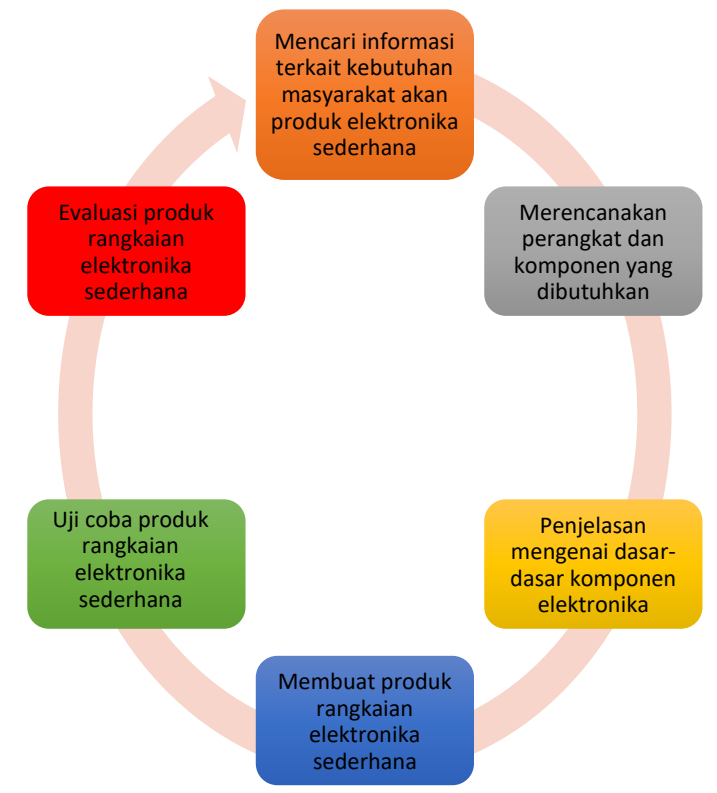

Gambar 2. Tahapan pembuatan rangkaian elektronika sederhana

Metode pelaksanaan dalam kegiatan pengabdian kepada masyarakat di lapangan yang telah dilakukan diawali dengan penjelasan mengenai dasar-dasar komponen elektronika, melakukan praktek bersama warga tentang cara membuat produk elektronika sederhana yakni senter sederhana, dan penjelasan langkah-langkah membuat dispenser hand-sanitizer otomatis.

Beberapa komponen-komponen elektronika sederhana yang dipaparkan adalah 
suplai daya, resistor, kapasitor, saklar, IC (integrated circuit), proximity sensor, dan baterai. Bahan dan alat yang dibutuhkan dalam membuat rangkaian senter sederhana adalah baterai 9 Volt, lampu LED 3 buah, konektor baterai, paku, tutup botol, dan lem tembak, seperti yang terlihat pada Gambar 3 .

Bahan-bahan yang dibutuhkan adalah bahan yang mudah didapatkan, beberapa di antaranya dapat menggunakan bahan bekas yang sering ditemukan di dalam rumah yakni tutup botol dan paku. Untuk membuat dispenser hand-sanitizer otomatis, bahan dan alat yang digunakan adalah sensor proximity, pompa air DC tipe celup, transistor TIP32C, selang aquarium, botol kaca/plastik bekas, ujung bolpoin bekas, cairan sanitizer.

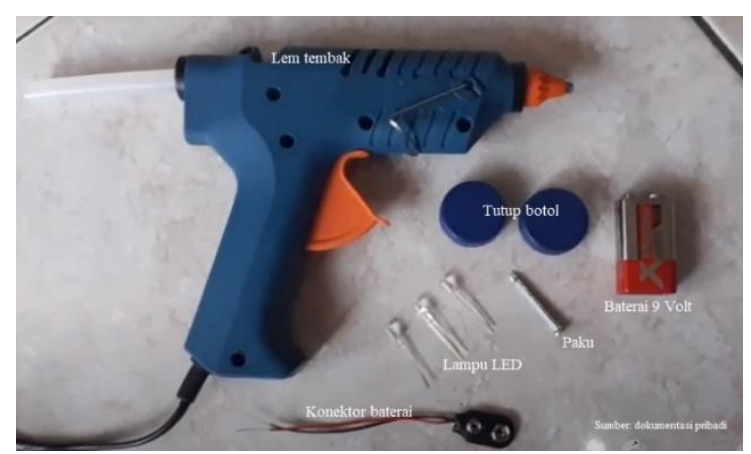

Gambar 3. Bahan Dan Alat Penyusun Senter Sederhana

\section{HASIL DAN PEMBAHASAN}

Kegiatan pengabdian kepada masyarakat yang dirancang oleh tim dosen program studi Teknik Elektro, Fakultas Teknik, Universitas Budi Luhur telah dilaksanakan di rumah belajar Kelompok Swadaya Masyarakat NYIUR yang berlokasi di Jalan Haji Gaim No. 50 RT 010 / RW 02 Kelurahan Petukangan Utara, Kecamatan Pesanggrahan, Jakarta Selatan pada bulan Agustus tahun 2020. Kegiatan workshop diikuti oleh 16 orang.

Agenda dibagi menjadi empat sesi, sesi pertama yakni pemaparan materi komponen rangkaian elektronika, sesi kedua adalah praktek pembuatan rangkaian lampu senter sederhana, sesi ketiga adalah penjelasan mengenai tahap-tahap membuat rangkaian dispenser, dan sesi terakhir adalah sesi tanya jawab.

Pada sesi pertama, pemaparan materi komponen-komponen rangkaian elektronika sederhana terlihat pada Gambar 4. Beberapa komponen yang dijelaskan adalah lampu LED dan perbedaannya dengan lampu pijar, baterai, sensor proximity berbasis sinar infrared, transistor, dan resistor.

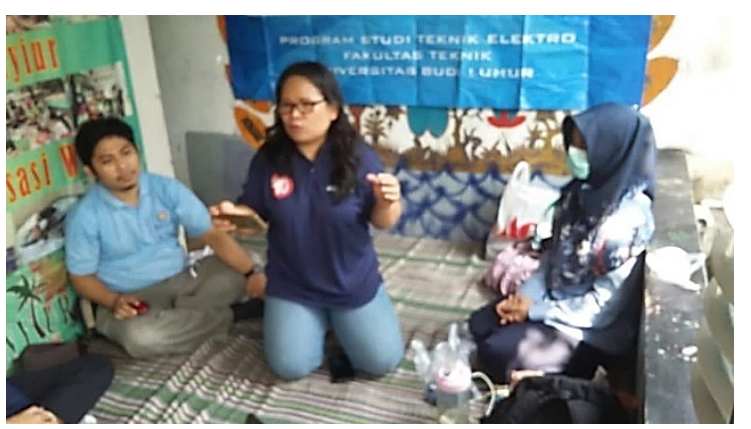

Gambar 4. Pemaparan Komponen Elektronika

Agenda berikutnya adalah seluruh peserta melakukan praktek pembuatan lampu senter sederhana yang dipandu oleh tim. Seluruh peserta workshop terbagi menjadi 4 kelompok dengan masing-masing kelompok terdiri dari 4 peserta. Setiap kelompok diberikan satu set komponen yang terdiri dari konektor, baterai 9 volt, dua tutup botol bekas, tiga buah lampu LED, dan paku. Seluruh peserta sangat aktif dan kooperatif. Gambar 5 adalah suasana peserta workshop saat membuat rangkaian lampu senter sederhana. Setelah mengikuti tahap-tahapan pembuatan lampu senter sederhana, setiap kelompok berhasil membuat satu buah lampu senter sederhana, seperti yang terlihat pada Gambar 6.

Evaluasi produk rangkaian elektronika sederhana dilakukan oleh tim dengan melakukan wawancara dengan peserta. Dengan adanya senter sederhana yang dapat dibuat dengan bahan-bahan yang mudah didapatkan, masyarakat dapat memanfaatkan produk tersebut sebagai lampu darurat.

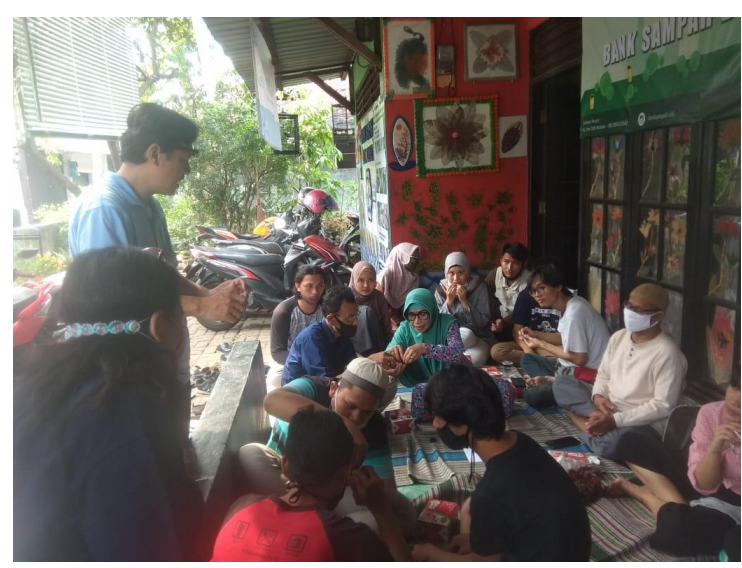

Gambar 5. Peserta workshop membuat rangkaian lampu senter sederhana 


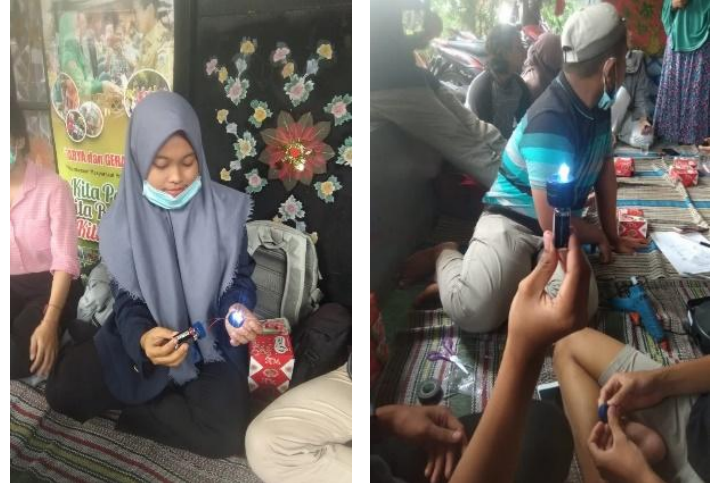

Gambar 6. Lampu senter sederhana yang telah dirakit oleh peserta workshop

Sesi ketiga adalah penjelasan mengenai prinsip kerja dan langkah-langkah merakit dispenser hand-sanitizer otomatis, seperti yang terlihat pada Gambar 7. Dispenser hand-sanitizer otomatis dapat membantu masyarakat untuk mencegah persebaran virus Covid-19 dengan cara membersihkan tangan tanpa perlu menyentuh dispenser tersebut. Sesi terakhir adalah sesi tanya-jawab sekaligus pembagian doorprize bagi peserta yang dapat menjawab pertanyaan-pertanyaan yang diajukan oleh tim, seperti yang terlihat pada Gambar 8.

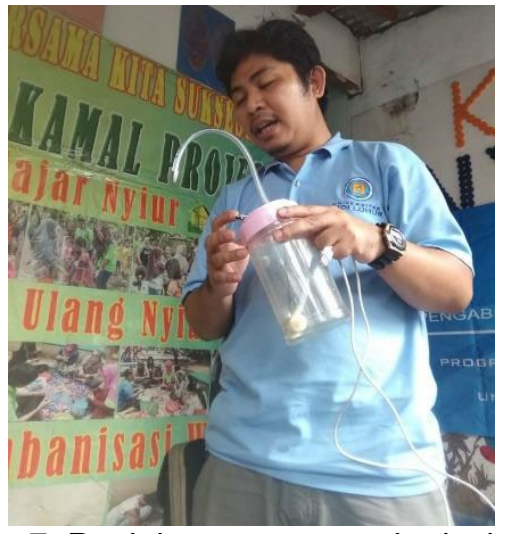

Gambar 7. Penjelasan mengenai prinsip kerja dan langkah-langkah merakit dispenser handsanitizer otomatis

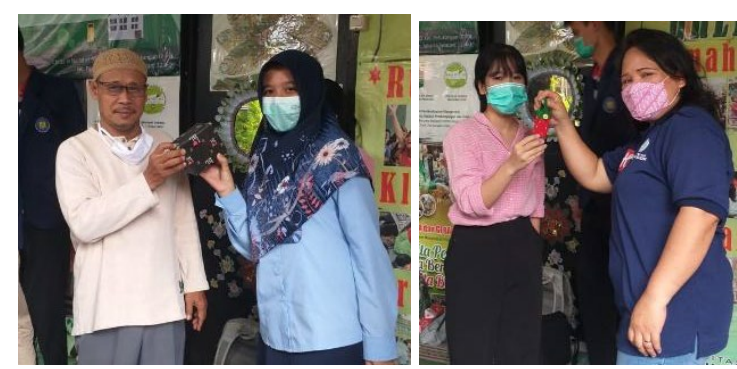

Gambar 8. Pembagian doorprize

\section{SIMPULAN DAN SARAN}

Berdasarkan agenda workshop yang telah dilaksanakan, peserta telah dapat memahami tentang dasar-dasar komponen elektronika. Hal ini ditandai dengan kemampuan seluruh peserta untuk dapat merakit sendiri lampu senter sederhana dengan bahan-bahan yang mudah didapatkan. Selain itu, peserta juga dapat memahami konsep pembuatan dispenser hand-sanitizer otomatis.

\section{DAFTAR RUJUKAN}

Amri, H., \& Stephan, S. (2020). Pelatihan Reparasi Peralatan Elektronik Rumah Tangga (Lampu Penerangan LED). Kumawula: Jurnal Pengabdian Kepada Masyarakat, 2(3), 192. https://doi.org/10.24198/kumawula.v2i 3.24514

Atmam, Zulfahri, \& Situmeang, U. (2017). Pelatihan Pembuatan Lampu Emergency Menggunakan Light Emitting Diode (LED) Bagi Siswa Sma Budhi Luhur Pekanbaru. JPPM LPIP UPM: JURNAL PENGABDIAN DAN PEMBERDAYAAN MASYARAKAT, 1(2), 103-107.

Atmam, Zulfahri, \& Situmeang, U. (2018). Pelatihan Penggunaan Komponen Dioda Pada Rangkaian Elektronika Bagi Mahasiswa Fakultas IImu Komputer Universitas Lancang Kuning Pekanbaru. Dinamisia: Jurnal Pengabdian Kepada Masyarakat, 2(1), 124-128.

https://doi.org/10.31849/dinamisia.v2i1 .1151

Mohammad Fadly Syah Putra, Sarah Purnamawati, \& Ainul Hizriadi. (2017). Pelatihan Rancang Bangun Peralatan Elektronik Menggunakan Raspberry $\mathrm{Pi}$ Untuk Siswa. ABDIMAS TALENTA: Jurnal Pengabdian Kepada Masyarakat, 2(1), 37-40. https://doi.org/10.32734/abdimastalent a.v2i1.2194

Rakyat, K. P. U. dan P. (2015). KSM Nyiur Berbagi IImu Daur Ulang Sampah. http://kotaku.pu.go.id:8081/wartaarsip detil.asp? mid=7805\&catid $=3 \&$

Risnandar, M. A., Sambas, A., \& Ula, S. (2019). PKM Pelatihan Perakitan Elektronika Sebagai Bekal Keterampilan Generasi Milenial Di Kota Tasikmalaya. MARTABE: Jurnal Pengabdian Masyarakat, 2(2).

Sekarsari, K., \& Sunardi. (2020). PELATIHAN ARDUINO UNTUK SISWA SISWI MTS SWASTA AL-MURSYIDIYYAH BENDA BARU PAMULANG. Jurnal Pengabdian Dharma Laksana Mengabdi Untuk Negeri, 3(1), 15-21. 
Waluyo, C. B. (2018). Pelatihan Pembuatan Running Text Berbasis Matrix Display Led Dengan Menggunakan Hd-U6a. KACANEGARA Jurnal Pengabdian Pada Masyarakat, 1(1), 7. https://doi.org/10.28989/kacanegara.v $1 \mathrm{i} 1.259$ 